\title{
A espiral poética e o tempo da criação em Rubiane Maia: notas em processo
}

Lindomberto Ferreira Alves ${ }^{1}$

\begin{abstract}
Suponhamos, por exemplo, que nós reagrupemos os elementos contemporâneos ao longo de uma espiral e não mais de uma linha. Certamente temos um futuro e um passado, mas o futuro se parece com um círculo em expansão em todas as direções, e o passado não se encontra ultrapassado, mas retomado, repetido, envolvido, protegido, recombinado, reinterpretado e refeito. Alguns elementos que pareciam estar distantes se seguirmos a espiral podem estar muito próximo quando comparamos os anéis. Inversamente, elementos bastante contemporâneos quando olhamos a linha tornam-se muito distantes se percorremos um raio. Tal temporalidade não força o uso das etiquetas 'arcaicos' ou 'avançados', já que todo agrupamento de elementos contemporâneos pode juntar elementos pertencentes a todos os tempos. Em um quadro deste tipo, nossas ações são enfim reconhecidas como politemporais. ${ }^{2}$
\end{abstract}

\section{Otempo à luz da multiplicidade}

EMBORA A EPÍGRAFE ACIMA TENHA A ASSINATURA DE BRUNO LATOUR, sua elaboração encontra eco nas inflexões de Michel Serres sobre o tempo à luz da multiplicidade - ou, para fazer jus à própria formulação

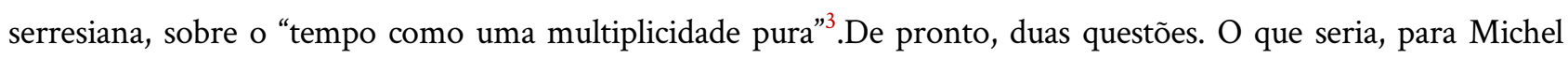
Serres, o tempo como uma multiplicidade pura? Em que medida, essa sua síntese enunciativa - esse modo singular de pensar o tempo que encontra ressonância em reflexões de autores como Gilles Deleuze (1999), Giorgio Agamben (2009), Jacques Rancière (2014), Muniz Sodré (2020), só para citar alguns - teria conduzido Bruno Latour à produção e exposição dessa imagem extremamente sofisticada que constitui o frame, compartilhado como epígrafe? Antes, é preciso advertir: longe de tentar responder questões de tamanha complexidade - o que implicaria um aprofundamento que escapa às próprias intenções desse texto - o esforço, aqui, é de indiciar certos aspectos que perpassam a problemática do tempo em Michel Serres e Bruno Latour, e que, aos nossos olhos, podem subsidiar algumas reflexões sobre a temporalidade que envolve os deslocamentos e desdobramentosatrelados à construção poética da artista multimídia contemporânea Rubiane Maia ${ }^{4}$ (Caratinga/MG, 1979), entre os anos de 2006 e 2016 recorte temporal que compreende os primeiros dez anos de carreira da artista.

\footnotetext{
${ }^{1}$ Mestre em Teoria e História da Arte (PPGA-UFES), Licenciado em Artes Visuais (UNAR/SP) e Bacharel em Arquitetura e Urbanismo (UFBA). Pesquisa processos de criação na arte contemporânea, de modo especial, em produções que colocam arte, vida e obra no mesmo plano de contágio. Integra o duo "FURTACOR", em parceria com a artista Amanda Amaral. Email: lindombertofa@gmail.com.

${ }^{2}$ LATOUR, B. Jamais fomos modernos: ensaio de antropologia simétrica. Tradução Carlos Irineu da Costa. Rio de janeiro: Editora 34, 1994. p. 74.

${ }^{3}$ Serres, M. Genèse. Paris: Grassei, 1982. p. 21.

${ }^{4}$ Licenciada em Artes Visuais (2004) pela Universidade Federal do Espírito Santo (UFES) e Mestra em Psicologia Institucional (2011), pela mesma instituição, Rubiane Maia é um dos mais importantes nomes da geração de performers,
} 
No que concerne à primeira questão, o que Michel Serres põe em jogo com esta formulação é uma compreensão que coloca em xeque a representação linear e progressiva do tempo, ancorada no paradigma do pensamento de matriz greco-europeia ${ }^{5}$. Essa seria, portanto, uma das bases para a construção de sua filosofia "uma filosofia que convém ao seu tempo." Segundo a perspectiva adotada por Serres para a formulação de sua síntese enunciativa sobre a compreensão da noção de tempo, seria necessário romper com a pretensa ambição unificadora do real (RANCIÈRE, 2014), tensionada pelo "liquidificador modernizante do Ocidente."” Ambição essa que predominou e ainda predomina - quer aceitemos ou não - em estratos significativos de diferentes campos epistemológicos, pautados na inteligibilidade colonialista da vontade de verdade enlaçada à ciência moderna ${ }^{8}$. Ambição que, de tanto suprimir e/ou dissolver, por exemplo, outras racionalidades alternativas

brasileiros e estrangeiros, à qual pertence, bem como um dos nomes centrais da produção contemporânea em Artes Visuais no Espírito Santo, surgidos no começo do século XXI. Radicada em Vitória/ES desde os quarto anos de idade, atualmente a artista vive entre Vitória (Espírito Santo, Brasil) e Folkestone (Reino Unido), percorrendo o mundo com seus trabalhos nas áreas da performance, do vídeo, da fotografia e do cinema. Explorando as possibilidades de expansão das potências do corpo, alinhada à invenção de si, por meio das mais diversas experiências performativas, ao longo dos seus recém-completos quatorze anos de carreira, Rubiane Maia não hesitou pôr-se em jogo na constituição de sua trajetória artística, fazendo uso de seu corpo e de suas próprias narrativas pessoais de vida como principal objeto e meio de sua arte.Trata-se de uma artista que contínua e intencionalmente coloca vida e obra no mesmo plano de contágio - isto é, que toma a vida como experimento da obra, e vice-versa. Plano no qual as fronteiras entre arte, vida e obra são constantemente redimensionadas, tensionadas e esmaecidas, e cujo tempo da criação mobiliza uma certa micropolítica da delicadeza ou da suavidade, com o fito de propor questões sobre os usos do corpo na arte e no cotidiano que incitem o desencarceramento dos modos de funcionamento vigentes da vida. A escassez de publicações da área que ascendam o interesse na pesquisa teórica e no exercício crítico acerca dos processos criativos agenciados no seu tempo da criação é, portanto, um dos motivos principais a moverem a escrita deste texto.

${ }^{5}$ Ver SODRÉ, M. Exu inventa o seu tempo. In: SODRÉ, M. Pensar nagô. Petrópolis: Vozes, 2020. p. 181-192.

${ }^{6}$ FrÉmont, C. Philosophie pour le temps présent. In: L'Yvonnet, F.; FrÉMOnT, C. (org.). Cahier de l'Herne No 94:Michel Serres. Paris: Éditions de l'Herne, 2010. p. 17-26. p. 17.

${ }^{7}$ CASTRO, Eduardo Viveiros de. O recado da mata. In: Kopenawa, Davi \& ALBERT, Bruce. A queda do céu: palavras de um xamã yanomami. Tradução Beatriz Perrone-Moisés. São Paulo: Companhia das Letras, 2015. p. 11-41. p. 15.

${ }^{8}$ É importante pontuar que não há, nesta crítica, qualquer oposição à ciência ou ao conhecimento em geral ou, ainda, qualquer pretensão de colocar em xeque a ciência em si - o que para Bruno Latour (2015), por exemplo, tratar-se-ia de um falso problema. O que se pondera com essa crítica, ou melhor, com essa autocrítica - vista, ainda hoje, lembra Georges DidiHuberman, como o diabo da história - é que o que se exerce ao longo dos tempos é a vontade de verdade (FouCAULT, 2012), ou melhor, a enunciação de discursos que funcionam entre diferentes práticas como justificação racional de verdade, como se fossem verdadeiros. Na trilha das reflexões foucaultianas, o que não podemos desconsiderar, e é aqui que esta autocrítica se faz necessária, é que essa vontade de verdade, que desliza ao longo da história humana, ancora-se em suportes institucionais, enlaçando-se, inclusive, com a ordem do discurso da chamada ciência moderna, da ciência enquanto conhecimento e, nesse sentido, da ciência como âmbito privilegiado e exclusivo da teoria do conhecimento. Vontade de verdade que em estratos significativos de diferentes campos epistêmicos, clivou, interditou, violou, rejeitou, silenciou e, em última instância, obliterou a alteridade, excluindo todo e qualquer tipo de epistemologias outras que não estivessem circunscritas e/ou chanceladas sob o julgo de uma pretensa ambição unificadora do real, contribuindo "fortemente para remeter para o domínio do irracional toda a razão não formada pela ciência" (SERRES, M. Diálogo sobre a ciência, a cultura e o tempo: conversas com Bruno Latour. Tradução Serafim Ferreira e João Paz. Lisboa: Instituto Piaget, 1996. p. 74). Isto posto, ante a verve da cientificidade, ao invés de assumirmos uma postura defensiva e nos inquirirmos se devemos ser ou não científicos, essa autocrítica não teria por intenção, outra, senão evocar olhares mais abrangentes sobre a ciência, sobre as vontades de verdade que ela inocula, bem como sobre o nosso próprio lugar, enquanto cientistas, de arvorados e exclusivos "porta-vozes" da episteme. 
(RIBEIRO, 2005) - e nelas formas dissensuais de temporalidade (SODRÉ, 2020; KOPENAWA \& ALBERT, 2015; KRENAK, 2020) via "o monopólio das formas de descrição do perceptível, do imaginável e do factível"” teria auxiliado no processo de homogeneização do tempo, tornando-o "cada vez mais linear e histórico." ${ }^{10}$ Em Michel Serres, importa pensar os saberes à luz do tempo como multiplicidade pura - ao que indica, posição alinhada à noção de simultaneidade dos tempos culturaisproposta por Walter Benjamin (1985); ou à atitude trans-histórica que perpassa ao pensamento histórico-filosófico defendido por Michel Foucault (2005); ou, ainda, de modo mais recente, à urgência de se repensar a historicidade das coisas mediante anacronismoscomo explorado por Georges Didi-Huberman (2015). Isso porque, para Serres, sob essa rubrica, os saberes operariam muito mais como "rede onde não há nem centro nem percurso privilegiado, porque as relações entre os saberes são múltiplas e ao final tudo se torna conexo" ${ }^{11}$. Assim, ele sustenta a compreensão dos acontecimentos, do fluxo das coisas - incluindo aí, por exemplo, o próprio tempo dacriação artística - que emergiriam em favor da construção dos nossos próprios conceitos a respeito do tempo. Conceitos esses afeitos ao descontínuo, a uma propagação caótica de emergências que substituísse "a vã questão da origem pela ideia de múltiplos recomeços de fundações"12 , ao invés de uma história legível, refém dessa concepção de tempo linear e cronológico.

Nessa operação,háa possibilidade de conciliar singularidade e totalidade, sem suprimir a inteligibilidade de uma narrativa global e tampouco perder o lugar e o valor de cada diferença e sua particularidade(SANTOS, 2016). É aí que parece residir a importância de se propor uma filosofia que convém ao seu tempo, especialmente por nossa época ser marcada por uma concepção de humanismo cujo sujeito é "cada vez mais descentrado de uma relação espaço-tempo" ${ }^{13}$. Uma filosofia que busca compreender as implicações conjunturais e contingenciais que essa concepção suscita exige "uma mudança de escala no tempo e no espaço de modo a dar-se conta do que há de novo no conhecimento" ${ }^{14}$. O que haveria de novo no conhecimento sob esse ponto de vista? Seguindo as pistas de Serres - ou as de Peter PálPelbart (2007)- seria a própria ideia de tempo. Pensar o tempo a partir de uma filosofia que convém ao seu tempo, tal qual ele se propôs, implica colocar em suspensão a ideia de tempo como a conhecemos: como uma categoria universal e unívoca, vinculado à ideia de progresso, que sustenta o narcísico esquema histórico hegemônico. Para Serres, isso não se trata do tempo. Mas de um jogo de concorrência, jogo dialético entre os que, no presente, reivindicam "o direito de reinventar a história ao seu proveito" 15 , tornando obsoletas outras temporalidades, ainda que, muitas vezes, "a tradição traga até nós alguns

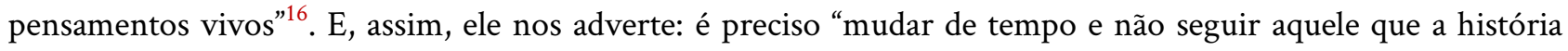

\footnotetext{
${ }^{9}$ RANCIÈRE, J. Op. cit., 2014, p. 215.

${ }^{10}$ PELBART, P. P. A vertigem por um fio: políticas da subjetividade contemporânea. São Paulo: Editora Iluminuras, 2000. p. 184.

${ }^{11}$ FRÉMONT, C. Op.cit., 2010, p. 18.

12 Ibidem, p. 23.

13 Santos, M. E. E. A multiplicidade como teoria da comunicação na filosofia de Michel Serres e suas contribuições para o pensamento em educação. 2016. 248 f. Tese (Doutorado em Educação) - Programa de Pós-Graduação em Educação, Faculdade de Educação, Universidade Estadual de Campinas, Campinas, 2016. p. 41.

${ }^{14}$ Ibidem, p. 41.

${ }^{15}$ SERRES, M. Op. cit., 1996, p. 73.

${ }^{16}$ Ibidem.
} 
utiliza" ${ }^{17}$, sobretudo porque a razão está "estatisticamente distribuída por toda a parte: ninguém pode reivindicar a sua posse exclusiva" ${ }^{\prime 18}$.

Desse modo, o tempo como multiplicidade pura, como a própria formulação insinua, não correria segundo uma linha, tampouco segundo um plano. O tempo, para Serres, corre segundo uma "variedade extraordinariamente complexa, como se aparentasse pontos de paragem, rupturas, poços, chaminés de aceleração espantosa, brechas, lacunas, tudo semeado aleatoriamente, pelo menos numa desordem visível” ${ }^{19}$. Nítida influência de Leibniz sobre as reflexões de Michel Serres (1968), especialmente no que concerne à concepção de progresso para aquele. Prolongando a discussão leibniziana acerca da noção de progresso, Serres perscruta a ideia de diferenciação em tempos elementares múltiplos - contrária a representação formal do tempo como uma linha, contínua ou entrecortada. É a partir desse prisma que Serres vai sugerir o tempo como turbulento, bifurcado, dobrado, caótico e paradoxal, fluindo sempre de maneira complexa, inesperada e complicada. Um tempo livre de qualquer teleologia, que "dobra-se ou torce-se; [...] uma variedade que seria necessário comparar à dança das chamas de uma fogueira: ora cortadas, ora verticais, móveis e inesperadas" ${ }^{20}$. Nele não existiria uma distância medida, geométrica, fixa e mensurável entre as coisas, apenas topologia: "ciência das vizinhanças e dos rasgões"21.

Rompe-se, portanto, com o arbitrado pela geometria métrica das distâncias bem definidas, e abre-se a percepção do tempo à dimensão multitemporal dos acontecimentos da história, onde o que acontece "remete para o passado, o contemporâneo e o futuro simultaneamente"22. Objetos e circunstâncias seriam, pois, policrônicos e multitemporais, dando a ver um tempo multiplamente dobrado. Nessas dobras do tempo, acontecimentos ou diferentes épocas que pareciam distantes podem estar mais próximos; com efeito, o contrário também seria possível. Assim, tempo como multiplicidade pura seria, na ótica da filosofia de Serres, "a emergência de uma diferença, ou melhor, acumulação de diferenças marcadas em conjunto indefinido" ${ }^{23}$ entendimento partilhado, também, por Gilles Deleuze (2006). Cada repetição de um mesmo operador engendrará mutações, afirmando a diferença via contingenciamentos. De toda sorte que implicaria a revisão da noção de novidade e das noções de resolvido e de passado. A esse respeito, Peter PálPelbart, à luz de Serres, pontua que é necessário "admitir que dificilmente somos co-presentes ao nosso presente, que somos muito mais arcaicos do que nos representamos, que o arcaísmo não é uma deficiência, e que ser contemporâneo de si mesmo já é algo extremamente complexo"24 - para não dizer raro, como lembra Giorgio Agamben (2009).

Se Michel Serres, como vimos, convoca diferentes imagens para mediar essa sua singular, mas não isolada, compreensão do tempo, é Bruno Latour, entusiasta confesso das reflexões serresianas, quem irá evocar a metáfora da espiral no intento de atribuir contornos à passagem do tempo. Convém destacar que ela é forjada

\footnotetext{
${ }^{17}$ Ibidem, p. 70.

${ }^{18}$ Ibidem, p. 74.

${ }^{19}$ Ibidem, p. 83.

${ }^{20}$ Ibidem, p. 84.

${ }^{21}$ Ibidem, p. 87.

${ }^{22}$ Ibidem, p. 86.

${ }^{23}$ FRÉMONT, C. Op.cit., 2010, p. 25.

${ }^{24}$ Pelbart, P. P. Op.cit., 2000, p. 185.
} 
bem no centro da crítica latouriana à ideia de modernidade ${ }^{25}$. Sem adentrarmos os meandros dessa crítica, no que concerne a presente discussão o importante é pontuar que, para Bruno Latour, a questão do tempo é central na concepção da própria ideia de moderno, uma vez que essa se constrói a partir das noções de progresso e evolução, que vão conferir ao tempo as feições de uma "seta irreversível" ${ }^{26}$, que progrediria rumo ao novo. A relação com o tempo teria a ver com uma "polaridade duplamente assimétrica: ora o tempo é marcado por uma progressão por saltos (revoluções), ora o tempo é marcado por um volumoso acúmulo de dados (inscrições) sobre os instantes de um passado a ser constantemente reconstruído" ${ }^{27}$.

No bojo deste "antidrama da revolução louca contra o conservadorismo sensato" ${ }^{28}$, a irreversibilidade no curso do tempo, que sempre agiu em nome de um pretenso progresso modernizador, é posta em xeque à medida que, segundo Latour, "um período histórico passa a dar a impressão de uma grande montagem" ${ }^{29}$, que media, mistura, elementos de épocas, ontologias e gêneros distintos. Entendimento, esse, que prolifera e encontra eco na assertiva "pós-moderna" de que "qualquer agrupamento contemporâneo é politemporal" ${ }^{30}$. No cerne deste debate, a ideia de dispersão colocará em questão o pelotão bem ordenado e verossímil dos elementos no espaço e no tempo, segundo os agrupamentos modernizadores, dando a ver o turbilhão no fluxo temporal. Sob essa ótica, torna-se cada vez mais complexo, ou mesmo problemático, reconhecer o lugar dos elementos ante a suposta ideia de fluxo regular do tempo, bem como "classificar em um único grupo coerente os atores que fazem parte do 'mesmo tempo"' 31 . Rompe-se com a temporalidade moderna. A passagem do tempo deixa de ser um fluxo laminar, contínuo e progressivo, e torna-se reversível, dispersivo e turbulento.

Entretanto, o único senão de Bruno Latour em relação aos pós-modernos é que, embora estes tenham razão quanto à dispersão, por outro lado, eles ainda parecem conservar a ideia de tempo como panorama geral. Para Latour, "o tempo não é um panorama geral, mas antes o resultado provisório da ligação entre os seres" ${ }^{32}$. Caminha, portanto, num sentido oposto a um tempo de todos os sistemas, num sentido da história. Diz ele: "o tempo nada tem a ver com a história. É a ligação entre os seres que constitui o tempo"33 e não "o calendário ou o fluxo que os modernos tinham construído para nós" ${ }^{34}$. Isso porque "nunca houve nada além de elementos que escapam do sistema, objetos cuja data e duração são incertas" ${ }^{35}$. O que ocorre é que todos acabamos misturando os tempos. Nesta operação, ao selecionarmos ativamente elementos pertencentes a tempos diferentes, passamos de uma temporalidade a outra. A esse respeito, ele nos lembra ainda que, em si mesma, uma temporalidade "nada tem de temporal. É uma forma de classificação para ligar os elementos. Se mudarmos o princípio de classificação,

\footnotetext{
${ }^{25}$ LATOUR, B. Op. cit., 1994.

${ }^{26}$ Ibidem, p. 72.

${ }^{27}$ CARdoso, T. S. A epistemologia da mediação em Bruno Latour. 2015. 284 f. Tese (Doutorado em Tecnologias da Inteligência e Design Digital) - Programa de Pós-Graduação em Tecnologias da Inteligência e Design Digital, Faculdade de Ciências Exatas e Tecnologia, Pontifícia Universidade Católica de São Paulo, São Paulo, 2015. p. 129.

${ }^{28}$ LATOUR, B. Op.cit., 1994, p. 72.

${ }^{29}$ Ibidem.

${ }^{30}$ Ibidem, p. 73.

${ }^{31}$ Ibidem.

${ }^{32}$ Ibidem, p. 74.

${ }^{33}$ Ibidem, p. 76.

${ }^{34}$ Ibidem, p. 74.

${ }^{35}$ Ibidem.
} 
iremos obter uma outra temporalidade a partir dos mesmos acontecimentos" ${ }^{36}$. É neste ponto que Bruno Latour evoca a metáfora da espiral. Com ela, delineia essa mudança na qual é possível se reconectar com a liberdade de movimento do tempo como multiplicidade pura - de Michel Serres, que tanto a modernidade negou - e, a partir da qual, podemos "abandonar as análises sobre o quadro vazio da temporalidade (moderna) e retornar ao tempo que passa, quer dizer, aos seres e a suas relações, às redes construtoras de irreversibilidade e reversibilidade” ${ }^{37}$. Com a imagem da espiral que prefigura na epígrafe de abertura deste texto, Latour esboça interesse pela passagem cuja temporalidade não nos força “o uso de etiquetas 'arcaico' ou 'avançado', já que todo agrupamento de elementos contemporâneos pode juntar elementos pertencentes a todos os tempos" 38 .

\section{Espiral poética: indiciando a volução ${ }^{39}$ dos processos criativos de Rubiane Maia}

Esclarecidas as duas questões iniciais, uma terceira emerge: por que tudo isso importa à discussão do presente texto? Por duas razões que se encontram em pressuposição. A primeira - que se veicula a hipótese central deste texto - é que embora os deslocamentos e os desdobramentos atrelados à construção poética da artista multimídia contemporânea Rubiane Maia, entre 2006 e 2016, possam ser examinados segundo uma estrutura cronológica e linear; enquanto forma, como acabamos de ver com as reflexões de Serres e Latour, essa organização no espaço e no tempo não dá conta de expressar a complexidade e os dinamismos que agenciam o tempo da criação, acabando por confinar Maia, seus processos criativos e seus trabalhos a um tempo linear, distanciado e apartado do tempo à luz da multiplicidade. A segunda razão é que, dada a observância analítica das questões conceituais, formais e existenciais que perpassaram os primeiros dez anos de carreira da artista ${ }^{40}$, percebemos que tanto a perspectiva serresiana do tempo à luz da multiplicidade quanto a metáfora latouriana da espiral do tempo revelam-se bastante adequadas para pensarmos e operarmos a discussão da temporalidade subjacente aos processos criativos da artista - uma temporalidade turbulenta e espiralada - posto que esses indiciam e apresentam múltiplos atravessamentos, continuidades, repetições, rupturas e desvios que escapam a síntese lógica do encadeamento cronológico de um continuum pontual, infinito e quantificado.

\footnotetext{
${ }^{36}$ Ibidem.

${ }^{37}$ Ibidem, p. 76.

${ }^{38}$ Ibidem, p. 74.

39 Para Maria Beatriz de Medeiros (2017), é um conceito que "pode sugerir sinais nomadizantes para pensar a arte contemporânea: [...] volução não é evolução, nem devolução, nem involução. Na volução não há progresso nem novidades. Nada é novo, tudo volui, re-volui e é iteração. Há volução, processos em voluta, em espiral rodando sem objetivo, sem jamais atingir o centro (inexistente), sem jamais manter um só movimento. A volução se aproxima da volúpia quando paixões deixam mentes-corpos tornando-se um corpus na pró-noia do prazer em grupo. As fragatas planam em volução. [...] Essa volução não se dá de mão em mão, é levada pelo vento” (MEDEIROS, M. B. Sugestões de conceitos para reflexão sobre a arte contemporânea a partir da teoria e prática do grupo de pesquisa corpos informáticos. In: ARJ, Natal/Porto Alegre, v. 4, n. 1, p. 33-47, jan.-jun. 2017. p. 42-43).

${ }^{40}$ Essas questões foram tratadas e recentemente publicizadas nos subcapítulos "Percursos na arte" e "Rumores de uma vida", da dissertação de mestrado de minha autoria, desenvolvida e defendida no âmbito do Mestrado em Artes, do Programa de PósGraduação em Artes da Universidade Federal do Espírito Santo. Ver: ALVES, L. F. Arte e vida em obra: a poética biografemática de Rubiane Maia. 2020. 300 f. Dissertação (Mestrado em Artes) - Programa de Pós-Graduação em Artes, Centro de Artes, Universidade Federal do Espirito Santo, Vitória, 2020.
} 
Razões essas advindas de um procedimento metodológico que inicialmente colocou, em relação, os apontamentos decorrentes das questões conceituais e formais que emergiram no trato analítico dos sessenta trabalhos ${ }^{41}$ produzidos por Rubiane Maia neste período, e a escuta sensível ${ }^{42}$ às impressões e às considerações da própria artista acerca da produção e circulação do conjunto de sua obra. E isso porque, nesse domínio ${ }^{43}$, o trato analítico não dizia respeito à mera escrita sobre os trabalhos da artista, mas, sim, à escritura (BARTHES, 2013) que se faz com/junto a eles. Pautado, portanto, neste entrecruzamento - que visou num primeiro plano a operação de um exercício teórico junto às principais linhas de força da poética de Rubiane Maia, entre 2006 e 2016 - constatou-se num plano secundário, mas não por isso menos fundamental, que a insistência de circulação de certas tendências (SALLES, 1998) davam a ver uma certa especificidade sobre o tempo da criação na artista, que aguçou a percepção à amplitude e à densidade das tramas poéticas que tecem a criação em Rubiane Maia. Percepção instaurada desde o primeiro contato com seus trabalhos - via o manejo dos múltiplos registros processuais, pessoais e artísticos - mas que só ganha tônus, ao ser confrontado com o modo como a própria artista compreende a noção de tempo; bem como essa sua compreensão, tal qual poderemos aferir, aqui, reverbera e ressoa na temporalidade que agencia as tramas de seus processos criativos.

Há de se registrar, inclusive, que é a partir desse confronto que chegamos às reflexões de Serres e Latour expostas anteriormente - e não o contrário. Ou seja, esta possível teorização a respeito da temporalidade subjacente aos processos criativos de Rubiane Maia compareceu à medida que aproximamos a dialogia entre as impressões da artista a respeito dos processos de produção dos trabalhos - e as nossas próprias junto a eles - ao campo teórico de Michel Serres e Bruno Latour. Neles, encontramos não só uma convergência em relação à maneira com a qual Maia pensa a questão do tempo, mas, também, o aporte teórico para se pensar a especificidade da temporalidade que tensiona as tramas poéticas que tecem a criação na artista, à luz do que propus chamar de espiral poética. Bem, inicialmente, faz-se mister observar que, se por um lado, a progressão no desenvolvimento dos sessenta trabalhos produzidos por Maia, nesse ínterim, cunhou uma trajetória artística expressiva e bastante consolidada; o saber-fazer artístico de Maia, por outro, embaralha o tempo linear, proliferando para além dele. Leitura que escapa ao espectro conjectural analítico e encontra respaldo em suas próprias palavras:

A contagem do tempo me parece super abstrata [...] o que vejo é que o contexto muda, as questões se ampliam e vão adquirindo maior complexidade, a gente entra e sai de muitos emaranhados, mas não existe isso de começo-meio-fim. ${ }^{44}$

41 Para visualizar os registros memoriais, bem como as imagens referentes a esse volume de trabalhos, acessar: $<$ https://www.rubianemaia.com/>.

${ }^{42}$ Foram pouco mais de 14 horas de conversas com Rubiane Maia, realizadas entre dezembro de 2018 e maio de 2020 sendo um encontro presencial e onze encontros por videoconferência. Objetivou-se estabelecer com esses encontros - que tiveram, cada um, duração média de uma hora e meia - um espaço dialógico e, sobretudo, de escuta sobre as impressões e as considerações da artista a respeito de sua trajetória artística e de sua construção poética, atendo-se no que nelas dizem respeito à singularidade dos modos com os quais a artista agencia o híbrido arte-vida-obra no campo de efetuações de seu saber-fazer artístico - foco da dissertação de mestrado de minha autoria.

${ }^{43}$ Alves, L. F. Op. cit., 2020.

${ }^{44}$ Ibidem, p. 103. 
Note-se que a compreensão da artista sobre o tempo parece operarem uníssuno com a síntese enunciativa, elaborada por Serres, do tempo à luz da multiplicade. Prisma segundo o qual coloca-se em xeque a tripartição passado, presente e futuro, uma vez que essa ideia parece falar muito mais de uma "abstração que separa tempo de espaço quando, na realidade, as três dimensões, espacialmente convergentes, são inseparáveis" ${ }^{35}$. Note-se, ainda, que os emaranhados a que ela se refere parecem chamar atenção para um tempo complexo, para um tempo impuro; em suma, para um rizoma temporal, ou seja, para "uma extraordinária montagem de tempos heterogêneos formando anacronismos" ${ }^{* 6}$. Aliás, a própria discussão didi-huberniana sobre a questão do anacronismo - sobre os "diferenciais de tempo operado em cada imagem [em cada acontecimento]" corrobora para a compreensão de que, ao invés de uma linha de tempo - como quer a perspectiva temporal dos calendários e relógios, sob tutela do "historiador fóbico do tempo" ${ }^{\text {- }}$ - tem-se um emaranhado, um turbilhão temporal em espiral, tal qual prefigura na metáfora latouriana da espiral do tempo.

Esta metáfora caminha na direção de compreensão da passagem do tempo a partir de saltos, acelerações, rupturas e diminuições de velocidades. Evoca, portanto, "não uma ordem do tempo, mas [uma] variação infinita, nem mesmo uma forma de tempo, mas um tempo informal, plástico" ${ }^{\text {"49 }}$. Esta visada convoca o anacronismo didihuberniano, a reversibilidade sodreniana, ou, para utilizar a expressão serresiana, o tempo da simultaneidade. Talvez por isso Rubiane Maia traçe linhas de fuga ao cotidiano historicamente normalizado, desliguando-se da "temporalidade dos acontecimentos, regida pela linearidade do antes e depois" ${ }^{50}$, de modo a voltar sua atenção na consciência do vivido temporal, isto é, no hiáto, no intervalo, na pausa, nesta "estreita nesga entre o passado e o futuro e cuja definição depende [evidentemente] das definições de passado e futuro" ${ }^{51}$. Isso indicia, aos nossos olhos, uma postura que alude para uma tomada de conciência das "vivências temporais compossíveis (não alucinatórias nem psicopatológicas) e não subordinadas à mecânica cronológica do trabalho e da história." ${ }^{25}$

Postura cuja força,ao operar a plasticidade que esta disponibilidade temporal exige, implica na mobilização, na aproximação, na contaminação e na dobra de seus interesses, de seus estudos, de suas pesquisas, de suas experimentações que invariavelmente acabam retornando em diferentes registros, acumulados sob camadas de distintos processos artísticos de $\mathrm{Maia}^{53}$. Postura afeita aos anacronismos, às reversibilidades, à simultaneidade. Afinal de contas, ao revisitar e deslocar o passado de seus processos criativos da condição de lembrança - de origem - atualizando-os, tornando-os contemporâneos uns dos outros, é como se ela nos chamasse atenção para

\footnotetext{
${ }^{45}$ SODRÉ, M. Op. cit., 2020, p. 184.

${ }^{46}$ Didi-Huberman, G. Diante do tempo: história da arte e anacronismo das imagens. Tradução Vera Casa Nova \& Márcia Arbex. Belo Horizonte: Editora UFMG, 2015. p. 23.

${ }^{47}$ Ibidem.

${ }^{48}$ Ibidem.

${ }^{49}$ PelBaRT, P. P. O tempo não reconciliado: Imagens de tempo em Deleuze. São Paulo: Perspectiva, 2004. p. 21.

${ }^{50}$ Ibidem, p. 191.

51 SAnTos, M. Por uma Geografia cidadã: por uma epistemologia da existência. In: Boletim Gaúcho de Geografia, Porto Alegre, v. 21, n. 1, p. 7-14, ago. 1996. p. 10.

${ }^{52}$ SODRÉ, M. Op. cit., p. 192.

${ }^{53}$ Uma imersão aprofundada neste aspecto pode ser empreendida através dos capítulos "Rubiane Maia em exposição portátil: à luz de punctuns e biografemas" e "Arte e vida em obra: a poética biografemática de Rubiane Maia”, constantes em: ALVES, L. F. Op. cit., 2020 .
} 
aquilo que, entre nós, parece encontrar resistência em ser pensado, de que "toda novidade reativa uma novidade anterior, análoga pelo problema a resolver e diferente pelas soluções possíveis" ${ }^{54}$. Nestes termos, a metáfora da espiral do tempo parece colocar uma lente de aumento que amplifica e traz para o visível e dizível aquilo que poderia não emergir por contra própria; isto é, o saber-fazer artístico de Rubiane Maia seria urdido através de uma espécie de espiral poética. Delineio a partir do qual permite-nos pensar a especificidade da temporalidade que tensiona as tramas poéticas que tecem a criação na artista. Tramas aparentemente forjadas a partir do trânsito turbilhonar e difluente entre diferentes dimensões temporais - via movimentos descontínuos e espiralados, tal qual uma pipa quando voa ou as labaredas de uma fogueira quando queima - em que o continuum da cronologia do tempo perde a sua pregnância e a noção de contemporaneidade (AGAMBEN, 2009) irrompe em toda sua potência. Movimentos difusos, contralineares e rizomáticos, instaurados na experimentação de uma modalidade outra de temporalidade, "donde temporalidade como articulação dos acontecimentos uns aos outros através do encaminhamento singular de uma [dada] experiência." ${ }^{55}$ Encaminhamentos que, em Rubiane Maia, parecem conjurar uma aposta bastante consciente da artista (como poderemos verificar, sequencialmente, por meio de seus relatos) na importância dos atravessamentos politemporais para que a relação entre sua poética entendida como urgência diante da precariedade humana (física, mental, emocional, social, existencial) - e a força do contemporâneo seja potencializada em suas ações, volua ${ }^{56}$. Assim, a cada volução desta sua espiral poética seu saber-fazer artístico nada tem a ver com um tempo que prometa a superação ou a revolução, mas sim com o tempo como multiplicidade pura; eterno retorno das questões, dos temas, dos elementos formais e conceituais, sempre marcados pelo signo da diferença.

Pois bem, se há, em Rubiane Maia, uma intencionalidade do tempo da criação ao eterno retorno das questões, dos temas e dos elementos formais e conceituais que perpassam os movimentos descontínuos e espiralados dos processos artísticos ao longo do tempo, ao que parece, ela operaria de modo potencialmente análogo ao arranjo descrito na epígrafe do início deste texto. De maneira que não nos pareceria equivocado,

\footnotetext{
${ }^{54}$ FRÉMONT, C. Op.cit., 2010, p. 26.

${ }^{55}$ SODRÉ, M. Op. cit., 2020, p. 186.

${ }^{56}$ Embora Maria Beatriz de Medeiros (Op. cit., 2017) em suas reflexõesnão se apoie em Michel Serres para delinear o conceito de volução, ao que indica, a emergência desse conceito encontra na discussão que Michel Serres (1968), à luz do pensamento leibniziano, faz sobre a concepção de progresso, uma importante aliada. Para ele, primeiramente é preciso "considerar a linha como modelo, ou seja, a representação formal [...], todavia, é preciso projetar depois a multiplicidade dessas linhas em um espaço de representação" (SERRES, M. Le système de Leibniz et sés modeles mathématiques. Paris: P.U.F., 1968. p. 285), de modo que o conjunto dessa multiplicidade de linhas engendre "uma superfície complicada, figura da evolução [volução?], que comportaria 'chaminés' de aceleração forte ou de crescimento infinito, passagens elevadas, paradas, ascensões, começo de descidas às zonas lineares estacionárias e assim por diante” (Ibidem, p. 285). Assim, o conceito de volução envolveria uma perspectiva acerca do movimento do fluxo das coisas que tensiona a face caótica e paradoxal da passagem do tempo, pois nessa superfície complicada de que nos fala Serres, "o tempo não corre, percola; isso quer dizer, justamente, que passa e não passa. [...] A teoria usual supõe o tempo em toda a parte e sempre laminar. Com distâncias geometricamente rígidas e mensuráveis ou pelo menos constantes. Um dia, dir-se-á que se trata da eternidade! Mas isso não é verdadeiro nem possível; não, o tempo corre de maneira turbulenta e caótica, percola” (SERRES, M. Op.cit., 1996, p. 8485). Bem, se levarmos em consideração que para Georges Bataille, todo problema, em certo sentido, é um problema de uso do tempo, junto a Michel Serres (1968; 1996), Bruno Latour (1994) e Maria Beatriz de Medeiros (2017), entendemos que isso se deve em virtude das nossas dificuldades sobre a teoria da história se assentarem "no facto de pensarmos o tempo dessa maneira insuficiente e ingênua" (Ibidem, p. 85).
} 
nesse sentido, pensar a noção de tempo no âmbito dos seus processos criativos, ou, para ser mais específico, a temporalidade subjacente aos processos criativos de Maia e, consequentemente, a urdidura de seu projeto poético à luz da figura conceitual espiral poética. E isso porque parece ser justamente em virtude dos atravessamentos politemporais, turbilhonares e difluentes que esta figura suscita, que as questões, os temas e os elementos formais e conceituais que a artista mobiliza em seus processos artísticos podem se encontrar permanentemente se cruzando nas volutas do seu tempo de criação em espiral - tempo que, como lembram Serres e Latour, expande-se em todas as direções e dimensões. Em outras palavras, nesta espiral poética esses elementos são trabalhados, retrabalhados, retomados a partir de articulações, composições e intensidades distintas, mas sempre presentes nas voluções das repercussões afetivas, bem como no entrecruzamento de diferenças dimensionais do "aqui e agora" dos processos artísticos dela.

Se como bem lembra Latour, "é a seleção que faz o tempo, e não o tempo que faz a seleção" ${ }^{57}$, residiria, portanto, no modo comoa artista sintoniza sua escuta aos devires sensíveis que percolam às voluções dessas repercussões e entrecruzamentos - operando aí a seleção dessas questões, temas e elementos formais e conceituais no "aqui e agora" dos processos que envolvem seus estudos, pesquisas e experimentações - a constituição do tempo do seu saber-fazer artístico, e não o contrário. Se, nesta seleção, é ela mesma quem faz a história dos seus deslocamentos e os desdobramentos atrelados à sua construção poética (instaurando o seu próprio tempo); parafraseando Muniz Sodré ${ }^{58}$, as ações de Rubiane Maia não estão dentro do tempo, elas o inventa. Invenção cujo tempo que engendra certamente não responde à revolução contínua do presente exortada pelo tempo moderno, e cuja noção de trajetória artística parece ser vista como sua reencarnação. Trata-se da invenção que aciona o tempo como multiplicidade pura; tempo no qual, necessariamente, nem se avança nem se recua. Tempo cujos desdobramentos e deslocamentos poéticos se encontram com a liberdade de movimento de seleção daquilo que faz parte do "aqui e agora" do tempo da criação - fazendo com que as questões, os temas e os elementos formais e conceituais voluam, se dobrem, se conectem e pertençam, simultaneamente, a tempos diferentes. Nesta construção, os trabalhos de Maia, que poderíamos considerar como distantes, só o são não por estarem distantes, segundo a perspectiva linear do tempo cronológico, e, sim, em virtude das distâncias entre as necessidades e os interesses evocados e selecionados no seio do "aqui e agora" do tempo da criação de seus respectivos processos artísticos. Assim como tornam-se próximos não por uma questão de proximidade temporal linear e cronológica, mas, sim, em decorrência dos anacronismos, das reversibilidades e das simultaneidades entre as necessidades e os interesses oriundos de tempos heterogêneos, agenciados na presentificação do tempo criação de seus respectivos processos artísticos. A este respeito, diz ela:

O passado está sempre em cruzamento com o presente, e a gente não acessa o passado puro, cru, mas sim com uma lente muito diferente, que é a do presente. [...] À medida que você vai fazendo, chega um momento em que você olha para o que está fazendo e começa a perceber que, claro, existem rupturas, mas, que também existem, e isso é muito forte, muitas coisas de tempos diferentes enganchadas umas nas outras. [...] Então, não existe um fim das coisas em si. O que percebo é que elas vão tomando diferentes formas e desenvolvendo uma espécie de

\footnotetext{
${ }^{57}$ LATOUR, B. Op.cit., 1994, p. 75.

${ }^{58}$ SODRÉ, M. Op.cit., 2020, p. 188.
} 
diálogo entre o que você está fazendo, entre o espaço vazio, o espaço que você ocupa e as questões que você começa a colocar em termos de conteúdo. ${ }^{59}$

Os processos artísticos de Rubiane Maia parecem envolver uma atitude que engendraum complexo jogo de forças entre passado, presente e futuro, entre os "ocorrido", os "agora" e os "por vir". Atitude cujos movimentos se quisermos lembrar, aqui, Walter Benjamin - exigem e mobilizam o abandono da típica atitude serena e contemplativa alicerçada na sintaxe casual da tripartição passado, presente e futuro, para "tomar consciência da constelação crítica em que esse preciso fragmento do passado se situa precisamente nesse presente" ${ }^{60}$ que, simultaneamente, dar a ver a formação de uma constelação de futuros por vir. Algo que parece reforçar a leitura de que, em sua espiral poética, Maia opera com deslocamentos e desdobramentos que mobilizam tempos heterogêneos, ou melhor, a coexistência de tempos distintos no seu tempo da criação. Nela, essas "coisas de tempos diferentes, enganchadas umas nas outras", não só "ressurgem no presente (sobrevivem para além de sua cristalização) como relâmpagos, lampejos, memórias involuntárias" ${ }^{\prime 1}$, como também, ao virem à tona, evidenciam tanto a complexidade, a amplitude e a densidade de suas tramas poéticas, quanto fazem emergir nexos escondidos e/ou invisibilizados, via uma operação sinóptica de diferenças que conduz à compreensão de outros possíveis por vir, acerca de seus processos criativos, baseados na própria diversidade e heterogeneidade.Estas considerações se fazem necessárias por uma razão bem simples: embora a artista não invista tanto tempo para entender isso a que ela se refere como "emaranhados", ou se quisermos, rizomas urdidos via repercussões e entrecruzamentos entre as questões, os temas e elementos formais e conceituais que seu tempo da criação seleciona - esses nexos, essas conexões entre as tramas dessa rede, que constitui o conjunto de seus trabalhos, não só existem como acabam evocando, sempre que estabelecidos, outros panoramas à sua poética, tonificando, ainda mais, tanto a maneira como ela própria enxerga seu saber-fazer artístico quanto como podemos enxergá-lo - como algo processual e, portanto, em constante volução. Nele, ao determinar certas restrições ou diálogos com essas repercussões e entrecruzamentos, Maia constitui as linhas de força que, naquele momento - ou seja, no "aqui e agora" singular de uma dada experiência - atribuirão contornos ao processo de criação relacionado à produção de um determinado trabalho. $\mathrm{O}$ que nos leva a atentar para o fato de que o tempo da criação artística é sempre marcado "por sua dinamicidade que nos põe, portanto, em contato com um ambiente que se caracteriza pela flexibilidade, não fixidez, mobilidade e plasticidade" ${ }^{62}$ - se quisermos nos remeter ao argumento de Cecília Almeida Salles (2006) sobre a criação como rede em construção. No limite, a criação responderia, nada mais e nada menos, ao tempo como multiplicidade pura. O que equivaleria dizer que o saber-fazer artístico de Maia parece estar em constante relação com as intensidades do tempo como multiplicidade pura; um fazer que, à maneira deleuziana, opera por meio de dobras, da multiplicidade de arranjos, conexões e atravessamentos - dado que "o múltiplo não é só o que tem muitas partes, mas que é

\footnotetext{
${ }^{59}$ Alves, L. F. Op. cit., 2020, p. 104.

${ }^{60}$ Benjamin, W. Passagens. Tradução Irene Aron. Belo Horizonte: Editora UFMG, 2009. p. 71.

${ }^{61}$ JACQUES, P. B. Montagem urbana: uma forma de conhecimento das cidades e do urbanismo. In: JACQUES, P. B.; BRITTO, F. D.; DRUMmOND, W. (orgs.). Experiências metodológicas para compreensão da complexidade da cidade contemporânea - Tomo IV. Salvador: EDUFBA, 2015. p. 47-94. p. 70.

${ }^{62}$ SALLES, C. A. Redes da criação: construção da obra de arte. Vinhedo: Horizonte, 2006. p. 12.
} 
dobrado de muitas maneiras" ${ }^{63}$. Operações que são mobilizadas pela artista através da conjunção de duas palavras que, no curso desse recorte temporal, passaram a se tornar caras ao tempo dos seus processos criativos: concisão e esgotamento. Sobre elas, Rubiane nos diz:

Eu encaro a concisão como um aspecto que me trouxe mais minimalismo para o meu trabalho. Porque, com ela, eu comecei a pensar e a gostar muito da ideia de esgotar uma ideia. E esgotar uma ideia, um conceito, pode gerar não uma, mas muitas performances. Então todas as vezes que eu tenho uma ideia, para desenvolver um trabalho, eu tento limpar. O que não é essencial? O que não é super importante? Se isso não é super importante, eu corto. Ou, então, se isso é tão importante e está competindo com outro, muito importante, eu divido. Isso virou uma espécie de metodologia de trabalho, que eu aplico até hoje. ${ }^{64}$

Esse breve relato da artista resume bem a complexidade sob a qual a produção dos trabalhos de Rubiane Maia está submetida - dando a ver, não somente, o modo como agencia metodologicamente os termos concisão e esgotamento no cerne de seu saber-fazer artístico, mas, também, como esse modo converge e corrobora com a leitura aqui empreendida acerca da especificidade do seu tempo da criação. Bem, se por um lado a ideia de concisão, no âmbito de seus processos criativos, parece revelar sua aposta no mínimo, no detalhe, naquilo que, a princípio, parece insignificante - e que, juntos, numa única ação, perderia sua potência por levar para muitas questões e horizontes diferentes. Por outro, a ideia de esgotamento parece aludir a sua aposta nos múltiplos desdobramentos que uma única ideia pode evocar quando decomposta em frames, os quais poderão ser acionados, retomados, refeitos, recombinados em temporalidades distintas e, consequentemente, reinterpretados segundo diferentes interesses e necessidades em constante volução, no âmbito de sua espiral poética. Sob o ponto de vista metodológico, juntos, esses termos parecem falar menos de um esgotamento lógico de possibilidades dadas e, mais, como nos lembra Georges Didi-Huberman, "da inesgotável abertura aos possíveis ainda não dados." ${ }^{\circ 5}$ É o caso, por exemplo, dos processos criativos vinculados às pesquisas de Rubiane Maia em torno da questão de memória $^{66}$. Trata-se de um campo de problematização cuja amplitude e complexidade que lhes são

\footnotetext{
${ }^{63}$ DeleuZe, G. A dobra: Leibiniz e o barroco. Tradução Luiz Orlandi. Campinas: Papirus, 1991. p. 13-14.

${ }^{64}$ ALVES, L. F. Op. cit., 2020, p. 105.

${ }^{65}$ Didi-Huberman, G. Atlas ou le gai savoir inquiet: L'oeil de l'histoire 3. Paris: Les éditions de Minuit, 2011. p. 13.

${ }^{66}$ A questão da memória, em Rubiane Maia, ganha contornos mais nítidos a partir do trabalho "Transferência. Talvez o nascimento das águas” (2012) - performance onde a memória emerge enquanto temática a ser investida a partir das lembranças do vínculo precocemente rompido com seu grande amigo e parceiro de projetos Marcus Vinícius, em virtude do seu falecimento, em 2012. Inclusive, no que concerne esse trabalho em especial, há de se destacar que as questões conceituais e formais iniciais, que o orbitavam em sua primeira exibição, puderam ser retrabalhadas e recombinadas a partir de outras configurações, em duas outras apresentações. Entretanto, ao operar um olhar um pouco mais atento e sensível à amplitude e à densidade das tramas poéticas que agenciam o tempo da criação em Rubiane Maia, é possível verificar que a questão da memória não só vem sendo acionada, retomada e reinterpretada em temporalidades distintas, desde seus primeiros trabalhos - a exemplo de "Pele. Superficie. Mercado" (2006), "Traços de ausência" (2007) e "Memória sonora" (2007), mobilizados à época pelos impactos das transformações das paisagens urbanas nas memórias afetivas da artista acerca dessas mesmas paisagens - como é possível observar, também, as ressonâncias metodológicas dos termos concisão e esgotamento sobre a questão da memória no âmbito das voluções de sua espiral poética, a exemplo dos trabalhos "Decanto, até quando for preciso esquecer" (2013) e "Antes que eu esqueça" (2014). Isso porque, apesar destes terem sido produzidos a partir do interesse e
} 
inerentes, aliada à aplicação dos princípios da concisão e do esgotamento como parte da sua metodologia de trabalho, foram permitindo à artista, em diferentes circunstâncias e a partir de diferentes perspectivas, trabalhála e retrabalhá-la tanto a partir de novas articulações e composições quanto a partir da repetição de uma dada articulação e/ou composição, marcadas sempre por intensidades distintas; possibilitando-nos, inclusive, apreendê-la por meio de uma espécie de apresentação sinóptica que não busca uma unidade a seu respeito, mas, sim, complexificá-la, justamente por acentuar suas alteridades constitutivas. E a cada vez que elas vão sendo retomadas, diz Rubiane Maia: "elas me trazem uma percepção diferente do tempo, dos afetos, das simbologias.”77 Note-se que, em sua espiral poética, as repercussões de seus processos artísticos - sejam eles relativos à questão da memória ou à outras questões, tais como espaço, tempo, paisagem, gênero, linguagem, ancestralidade, autocuidado, só para citar algumas - estão permanentemente se entrecruzando. E cada entrecruzamento parece se conformar como uma oportunidade, conforme destaca a artista, para "esgotar ou, pelo menos, tentar esgotar algumas possibilidades, [...] continuar experimentando algumas possibilidades dessas relações" ${ }^{68}$ entre trabalhos e processos, assim como entre as questões, os temas e os elementos formais e conceituais que eles mobilizam.A esse respeito, ela pontua:

O que eu fiz, já fiz. Ao mesmo tempo, algumas coisas permanecem muito vivas e elas voltam na minha cabeça, sempre como links de coisas que eu estou fazendo na atualidade. Claro, existem coisas que são impossíveis de não sofrer uma transformação muito grande. Mas é muito interessante perceber como elas aparecem e reaparecem, com diferentes perspectivas na materialidade; como essas coisas vão se transformando. ${ }^{69}$

Como fica nítido em sua fala, ainda que o exercício de reflexão sobre os trabalhos já realizados não seja propriamente uma prioridade no seio de seus processos criativos - tal qual destacado anteriormente - isso não significa que a própria artista não perceba, ou que nós mesmos não possamos perceber, os nexos e as conexões entre eles. Diz ela: "as coisas estão o tempo todo se cruzando, a gente pode fazer vários cruzamentos de um trabalho com o outro, em diferentes tempos, e esses cruzamentos eles vão existir."70 Assim, por mais que esses nexos e essas conexões não sejam necessariamente explícitos - como seria, por exemplo, via o estabelecimento de séries de trabalhos - eles revelam-se em constante volução no tempo da criação à maneira de Rubiane Maia: nas delicadezas e sutilezas com que ela instrumentaliza, no tempo de seus processos criativos, o compromisso com os sentidos das palavras concisão e esgotamento em favor da potência volutiva interna às próprias ideias e, invariavelmente, aos processos de criação que elas podem suscitar. Indo além, arrisco-me a dizer que seriam

do desejo da artista em investigar a incapacidade humana de esquecer (um claro efeito das perdas que sofreu neste período, e das implicações do tornar-se estrangeira em seu próprio país e em tantos outros por onde transitou), no primeiro ela busca, por meio da performance, forjar procedimentos através dos quais o esquecimento pudesse emergir como possibilidade; enquanto que no segundo, por meio do vídeo, ao se debruçar sobre os modos de funcionamento da memória, transformando a primeira parte da performance "Decanto, até quando for preciso esquecer" em uma ação de longa duração, ela joga com o binômio lembrança-esquecimento a fim de estabelecer outro tipo de tensionamento da memória no corpo.

${ }^{67}$ ALVES, L. F. Op. cit., 2020, p. 106.

${ }^{68}$ Ibidem.

${ }^{69}$ Ibidem.

${ }^{70}$ Ibidem. 
essas conexões, esses nexos escondidos e/ou invisibilizados, que dão tônus à nossa leitura, não só sobre seus processos artísticos como sendo politemporais - prenhes de dobraduras poéticas forjadas nesse seu tempo de criação turbilhonar e espiralado - mas, também, sobre como essa mesma leitura implica uma aproximação à singularidade de sua construção poética. Ao que indiciam nossas análises junto a esses nexos e a essas conexões que proliferam na trajetória da artista, o que subjazeria às voluções de sua espiral poética seriam as intenções reveladas de indissociação entre arte, vida e obra, à medida em que contínua e intencionalmente coloca vida e obra no mesmo plano de contágio - isto é, que toma a vida como experimento da obra, e vice-versa. Tendência que no âmbito do projeto poético de Maia parece conduzi-la à afirmação da vida como potência de criação território existencial ético-estético (GUATTARI, 1992) que explora a capacidade da arte em se manifestar como um "laboratório ético, estético, poético e político do sensível, da heterogeneidade, do outramento."71

E se essa zona de indeterminação e de indiscernibilidade, forjada nas adjacências das mutações entre arte, vida e obra, parece se constituir como espaço-tempo por onde o tempo da criação dos processos artísticos de Maia volui, é imprescindível frisar que é no corpo - no próprio corpo da artista - que ele é agenciado. Perspectiva que é reforçada em seu statement - espécie de carta de intenções utilizado por artistas para sintetizar suas propostas artísticas - na qual declara o interesse em “[...] fazer uso do corpo para ampliar suas possibilidades de percepção para além do habitual, por meio de uma constante (re)elaboração de sua própria noção de território existencial (espacial, temporal, social, cognitivo etc.)."72 Maia parece saber muito bem que qualquer tentativa de alinhamento de seus processos criativos, ao entendimento de suas relações com diferentes temporalidades - com a coexistência de tempos heterogêneos que não cessam de agenciar as cotidianidades do mundo - passa, necessariamente, pelo corpo, ou melhor, pelos usos que faz do seu corpo. Isso porque são das gestualidades que emanam das corporeidades desse corpo ante às intervenções, às linhas de fuga, às bifurcações, aos devios e às fricções entre ele, que efetivamente o espaço e o tempo desvelam os "arranjos e rearranjos desse corpo em relação aos espaços-tempos do viver" ${ }^{\text {- }}$ - conduzindo-a, portanto, ao encontro "da vida como processo." "74

Nota-se, assim, o quanto que a singularidade da construção poética de Rubiane Maia parece se conformar como uma espécie de dobra, na qual tempo, corpo, cotidiano e processos de subjetivação se entrecruzam, se entrelaçam e voluem - visando, aí, a instauração de outros modos de olhar e de estar na vida, outros modos de olhar para si mesma e para o mundo contemporâneo. Ao perseguir e forjar, para si, modos outros de invenção de si (FOUCAULT, 2004) - via uma perspectiva expansiva de suas práticas que instauram e perscrutam a indissociação entre arte, vida e obra, ponto de indistinção entre processos de vida e processos artísticos - é a própria existência de Maia que passa a ser alvo de seu saber-fazer artístico, de sua espiral poética. Em outras palavras, é sobre a sua própria vida e o que está a sua volta que seu tempo da criação se debruça e volui. Isso significa que, nela, cada projeto, cada performance, cada experiência - no sentido mais largo do termo - são mobilizados como espécies de práticas que inoculam "um trabalho ético sobre si, uma política em si, uma criação

\footnotetext{
71 Silva, R. V. M. Desvios, sobre arte e vida na contemporaneidade. 2011. 142 f. Dissertação (Mestrado em Psicologia Institucional) - Programa de Pós-Graduação em Psicologia Institucional, Departamento de Psicologia, Universidade Federal do Espírito Santo, Vitória, 2011. p. 8.

72 Idem. "Statement": carta de intenções artísticas. In: Silva, R. V. M. Homepage Rubiane Maia, [S.I., s.d.]. Ver: $<$ https://www.rubianemaia.com/bio>.

${ }^{73}$ Idem. Op. cit., 2011, p. 100.

${ }^{74}$ Ibidem, p. 96.
} 
de $s i$, que faz as sensações se dobrarem, se redobrarem, se desdobrarem em múltiplas afirmações" ${ }^{\text {"75 }}$. Práticas que, voltadas ao trabalho sobre si mesma, tornam-se capazes de engendrar novos territórios existenciais, nos quais sua vida evoque, descubra e extraia o que nela se encontra em vias de devir. Práticas que assumem os processos artísticos, portanto, como laboratório de constantes procedimentos de experimentação de formas-subjetividades que convoquem à criação e à recriação de si e de sua visão de mundo. Espaço-tempo em que sua vida é posta em jogo e não somente como objeto e meio de sua arte, mas, principalmente, como instância através da qual se é possível vislumbrar novos modos de vida, modificando seu próprio ser, sua própria vida. Algo que se torna tanto mais evidente quanto ganha contorno cada vez mais concretos, à medida que sua espiral póetica convoca o público ao compartilhamento da "criação, [d] a constituição, [d]a invenção de si como sujeito, em suas dimensões estéticas, éticas e políticas." ${ }^{76}$ É o caso, por exemplo, dos processos que levaram à produção da performance de longa duração "O Jardim"77 (2015).

No âmbito de sua espiral poética, tratou-se de uma dessas oportunidades referidas pela artista para continuar experimentando algumas possibilidades suscitadas pela ideia que, anos antes, em 2012, levou à realização de "Jardín secreto - porque deseo creer". ${ }^{78}$ Pois bem, se "Jardín secreto - porque deseo creer" (2012), emerge como uma espécie de saída da dor, do adormecimento e do estado de luto decorrente da falecimento precoce de um grande amigo - e que vislumbrou na germinação e no cultivo de feijões um modo de se relacionar com a morte e a vida, ao mesmo tempo; em "O Jardim" (2015), ao propor o cultivo de um jardim de feijões, a partir de uma nova e complexa configuração, ela parece estar interessada em experimentá-lo como uma via prolífica para se explorar exercícios de autocuidado, aplicados a si e ao outro, e neles os desdobramentos clínicos ${ }^{79}$ que nossas próprias ações, desde as mais ordinárias, são capazes de suscitar. Nesta nova e complexa configuração, o trabalho parece falar do desejo de Rubiane em "acolher a processualidade, e não estacar o processo" ${ }^{80}$. Desejo de "abrir-se às turbulências, [de] deixar-se contaminar por toda a carga de futuro, de imprevisibilidade, e com elas criar composições" ${ }^{\prime 1}$ de si e de mundos, nas quais a vida vai encontrando canais de efetuação para se afirmar como ilimitada atividade criadora. Em "O Jardim" (2015), é precisamente isso que a artista traz para o campo do visível: a "criação e a invenção de outros modos de percepção e de relação com o vivido, porosidade à flor da pele, passagem de afetos” ${ }^{\sharp 2}$. Para tanto, ela lança mão do cultivo de um jardim a partir de uma pequena plantação de feijões em

\footnotetext{
${ }^{75}$ Domingues, L. À flor da pele: subjetividade, clínica e cinema no contemporâneo. Porto Alegre: Sulina, 2010. p. 18.

${ }^{76}$ Idem. Ensaios de subjetivação: ethopoética, cartografemas e ethografias. In: LEÃO, A. et al (org.). Produção de subjetividade e institucionalismo: experimentações políticas e estéticas. Curitiba: Appris, 2017. p. 181-197. p. 183.

${ }^{77}$ Performance que integrou a mostra "Terra Comunal - Marina Abramović + MAI", em exposição no Sesc Pompeia, SP, Brasil, de 10 de março de 2015 e 10 de maio de 2015, e com curadoria de Marina Abramović, Paula Garcia e LynseyPeisinger.

${ }^{78}$ Performance desenvolvida no âmbito da residência artística "Cal Gras - Alberg de Cultura e Residência Artística”, sediada no povoado de Avinyó, em Barcelona, na Espanha, e apresentada entre 01 de outubro e 04 de novembro de 2012.

${ }^{79}$ Os desdobramentos clínicos a que nos referimos, aqui, não é o da clínica que evoca o conhecimento de si como busca de uma pretensa verdade sobre a natureza humana (FOUCAULT, 1977); mas, sim, o da clínica que aciona outras práticas de cuidado, capazes de operar pelos afetos, pelas multiplicidades, pela criação e pela liberdade - algo que Lygia Clark, por exemplo, ao longo de sua trajetória, procurou acionar em suas proposições.

${ }^{80}$ SILVA, R. V. M. Op. cit., 2011, p. 129.

${ }^{81}$ Ibidem, p. 126.

${ }^{82}$ Ibidem, p. 8.
} 
meio a arquitetura cinza, de puro concreto, da sede do Centro Cultural Sesc Pompeia (SP). Espaço-tempo concebido como uma espécie de laboratório vivo e em constante processo de transformação para experiências de cultivo e plantio, no qual a vida pôde ser continuamente manipulada, testada, cuidada e observada - do nascimento à morte - em uma escala tão sutil que exigiu, da artista e do público, tanto o desenvolvimento de outro tipo de relação com o tempo, quanto outro tipo de partilha do sensível (RANCIÈRE, 2005).

Com a atenção voltada para esse microcosmo, ao mesmo tempo que a artista e o público são confrontados com a incapacidade de perceber a olho nu as minúcias, as formas e as transformações contínuas dos dinamismos espaciotemporais que perpassam as voluções da vida; eles são, também, convidados a acompanhar todo esse processo, que se altera de maneira lenta, quase imperceptível, todos os dias. Experimenta-se, assim, uma espécie de vínculo, de cumplicidade; afinal de contas, dada a inaptidão do olho de não perceber tudo - nesse caso, o crescimento do feijão, a olho nu, até se tornar jardim - o trabalho parece tensionar em nós o desejo de uma temporalidade outra, que diferentemente da condição sine qua non de existência da arte que entretém ${ }^{83}$ (e que não por acaso segue o tempo exortado pela história), possa ser capaz de suscitar uma maior atenção ao processo em si, bem como o contato intensivo com a coexistência de tempos heterogêneos que agenciam todo o crescimento dos feijões - desde a preparação da terra, passando pelos múltiplos recomeços e movimentos descontínuos entre as diferentes fases do ciclo de desenvolvimento da planta: o brotar, o nascer, o crescer, o viver, o morrer - até que se constituísse o jardim.

Aí, o que parece nos atravessar é a própria formalização estética das metamorfoses da vida, explícita nesse espaço-tempo de cuidado da artista com seu jardim, que silenciosamente também se transmuta junto com ele. O que equivale dizer que, neste trabalho, a performance parece se dar entre ela, a artista, e o jardim; ou seja, é a própria vida em suas instâncias politemporais se manifestando através do crescimento dos feijões, que é objeto de/da performance. Indo além, podemos dizer que são os próprios feijoeiros e o tempo que performam no trabalho - quando observados, por exemplo, os desenhos contidos nos fragmentos dos diários que tentam capturar e registrar o movimento da vida se manifestando. Segundo Rubiane Maia, "plantar, colher, cuidar de um jardim, pode ensinar bastante, não apenas sobre a vida, mas, sobretudo, sobre a morte - no sentido de se estar lidando com a delicadeza da vida" ${ }^{\prime 4}$. Ou seja, do mesmo modo que os feijões, naquele contexto, tanto poderiam crescer e constituir o jardim quanto poderiam morrer a qualquer momento, o esforço de Maia neste trabalho parece ser o de chamar atenção para o fato de que a própria vida tanto pode crescer eseguir seu fluxo por caminhos mais potentes, quanto pode padecer, a qualquer momento, às incansáveis tentativas de

\footnotetext{
${ }^{83}$ Isso porque, conforme destaca Rubiane Maia, na lógica do entretenimento, não há tempo a perder. No seu caso, tudo se complexifica na medida em que suas performances evocam um outro tipo de temporalidade e, consequentemente, um outro tipo de experiência comum do sensível - diversa ao modus operandi de existência da arte que entretém. Em suas performances, não é o espetacular que é mobilizado. Do mesmo modo, se você as olhar com pressa, dificilmente conseguirá acessar as múltiplas camadas - quase imperceptíveis - que dão tônus às suas ações performativas. Ela sabe que se tratam de performances que não capturam qualquer pessoa - especialmente as de longa duração. É preciso ter disposição à proximidade e tempo de permanência para estabelecer intimidade com as sutilezas que pululam delas. Aliás, nelas, o tempo é crucial. Porque existe, nas entrelinhas, um convite silencioso: "quero roubar um pouco do seu tempo". (ALVES, L. F. Op. cit., 2020, p. 93)

${ }^{84}$ Trecho do depoimento de Rubiane Maia sobre a performance "O Jardim" (2015) para o vídeo da exposição "Terra Comunal - Marina Abramović + MAI". Ver:<https://www.youtube.com/watch?v=pi7iPi05nag\&t=16s>.
} 
empobrecimento das relações politemporais que podemos constituir com as nossas próprias existências. É redefinindo sutilmente o foco de atenção para o ciclo de vida dos feijões - assumindo como matéria de expressão artística a própria natureza instável, efêmera, minuciosa, frágil, misteriosa e politemporal da existência - que Maia compõe um "corpo-sentido de dizibilidades e visibilidades" ${ }^{\prime 2}$, com o qual ela aprende a transmutar as frustrações da perda, de modo a lidar com um processo que nasce, cresce, vive, morre e nasce de novo, dia após dia, afinal de contas, "tudo recomeça sempre - sim, uma vez mais, de novo, de novo" ${ }^{86}$. Ao fazer isso, ela nos lembra de que a vida precisa de tempo, mas não daquele que a história utiliza. A vida precisa de tempo de observação, de tempo de autocentramento, de tempo de silêncio e, sobretudo, de tempo de cuidado. Aliás, parece passar justamente pelo cuidado e pela sensibilidade com que ela gesta a coexistência desses tempos no âmbito do seu saber-fazer artístico, a capacidade de instaurar situações em que o público, assim como ela, sinta-se compelido ao compartilhamento da criação de si e de novas relações com o mundo em suas instâncias éticas e políticas. Indo além, é tensionando em nós a atenção e a percepção desses tempos outros que parece estar incutida a efetividade de um tipo de simbolização e de cognição não alienada entre arte, vida e obra. Muito mais diversa e complexa em relação ao atual status quo em que o tempo da lógica espetacularizada da arte opera junto à realidade.

\section{Arte e vida em obra: ou, sobre o que se debruça o tempo da criação em Rubiane Maia}

Se é a vida, ou melhor, a própria vida de Rubiane Maia que é o foco de suas dobraduras poéticas - atribuindo direção e sentidos aos deslocamentos de sua espiral poética - torna-se impossível falar de seus processos artísticos sem tocar nos seus processos de vida, e vice-versa. Qualquer pessoa que se dedique à investigação de sua trajetória artística dificilmente poderá negligenciar a sobredeterminância que suas histórias de vida exercem no processo de análise de sua construção poética. Não querendo dizer com isso que a justificativa dos percursos trilhados por Maia, no campo artístico, residiria em suas histórias de vida, e vice-versa - afinal de contas, não se trata, aqui, "de espreitar a biografia por baixo da superfície da obra, tampouco explicar a existência do criador em função das circunstâncias de sua vida privada" ${ }^{n 7}$. Apontar para a importância de uma atenção às histórias de vida de Maia, no âmbito de sua construção poética, visa demonstrar que, tal qual apontou nossas análises junto à trajetória dos seus dez primeiros anos de carreira $^{88}$, o movimento de uma invariavelmente acaba por movimentar a outra - num regime fluxionário de circularidade permanente. Ou seja, ao colocar intencionalmente arte, vida e obra no mesmo plano de voluções de sua espiral poética, Maia dar a ver o turbilhão no fluxo temporal que pressupõe reciprocidade, sobreposições, reversibilidades e atravessamentos mútuos entre o movimento da vida e o movimento da obra. O que implica dizer inclusive que, sendo a construção dos seus percursos de vida simultaneamente a construção dos seus percursos artísticos, e vice-versa, o tempo da criação na artista mobilizaria, concomitantemente, aspectos relacionados aos processos artísticos e aos processos de vida, dada a tendência de contágio circular entre eles no âmbito das voluções de sua espiral poética.

Se considerarmos, ainda, que o saber-fazer artístico de Maia se realiza em um "aqui e agora" que agencia passado, presente e futuro simultaneamente, podemos conjecturar, baseado no estudo de caso aqui apresentado,

\footnotetext{
${ }^{85}$ Domingues, L. Op. cit., 2010, p. 17.

${ }^{86}$ BlanchOt, M. O espaço literário. Tradução Álvaro Cabral. Rio de Janeiro: Rocco, 2011. p. 266

${ }^{87}$ BoURRIAUD, N. Formas de vida: a arte moderna e a invenção de si. São Paulo: Martins Fontes, 2011. p. 126.

${ }^{88}$ Alves, L. F. Op. cit., 2020.
} 
que ele haver-se-ia eticamente com o vetor de ativação da criação da vida, que tanto aciona quanto afirma o tempo à luz da multiplicidade. Isso porque, na artista, a invenção de novos modos de existência envolve e evoca, por si só, um tempo da criação cuja coexistência e sincronia de tempos distintos pressupõem aproximações, afastamentos, tangências, atritos e contaminações entre as matérias de expressão do mundo. É sintonizando seu corpo ao "aqui e agora" do campo invisível de voluções das forças e dos afetos que, em vias de constituição, não cessam de evocar, simultaneamente, a sincronia de tempo distintos e de maneiras singulares de viver, que a artista ativa a própria vida enquanto potência criadora, força de invenção. É nessa escuta que ela, consequentemente, afirmará que "recriar a si mesmo e a própria vida é um processo infinito de alçar sempre novas composições de si mesmo e do mundo." ${ }^{89}$ Para tal, conforme destaca Michel Serres, é preciso um outro tempo. Nos lembra a própria artista: "nossa força de existir pulsa muito mais pela construção dessas vias de escape do que de espaços etempos de confinamentos." ${ }^{90}$ É de posse desse entendimento que Maia passará a apostar em uma positividade criadora e inventiva "pela construção de práticas artísticas que na sua atuação poética [...] compõem um feixe de relações [politemporais] capazes de gerar outros modos de partilha e subjetivação que escapam aos modelos" ${ }^{91}$ de subjetividades vinculados aos modos de vida dominantes ${ }^{92}$.

O que indica que, junto à construção dessas vias de escape do espaço e do tempo hegemônico, é possível, sim, vislumbrarmos o "apossar-se das sensações para criar sentidos e por meio desta experiência transmutar-se ou ver e dizer outras coisas, de outras formas, sob outros ângulos, perspectivas, sonoridades." ${ }^{93}$ E apossar-se delas a fim de instaurar "encontros com a alteridade, com o desmanchar do Idêntico, com o 'outramento" 94 , parece implicar, inapelavelmente, que pensamos, acionamos e afirmamos a criação da vida à luz do tempo da multiplicidade. Algo que parece nos conduzir ao seguinte entendimento: se não é possível atribuir uma direção unívoca ao tempo como lembram Serres e Latour - isso se deve, em grande medida, ao caráter criador da vida, que arrasta sob suas linhas de fuga uma gama de processualidades e coexistências espaciotemporais que escapam a qualquer tipo de sobrecodificação teleológica. Nesses termos, não são somente os processos artísticos em Rubiane Maia que se revelam como politemporais, mas, também, os próprios processos de vida. Em cada ação, a artista opera a dobra de sua vida, aproximando tempos, espaços, circunstâncias e forças distanciadas, e distanciando tempos, espaços, circunstâncias e forças próximas. Dobras que mobilizam a constituição de formas-subjetividades provisórias, que à luz de tempos heterogênos engendram ilimitadas combinações de existências possíveis. Dobras que entrelaçam, misturam e embaralham matérias de expressão que, em vias de constituição ante a existência que devém de cada ação, atribuem tônus e singularidade a sua poética. Apostar nesses atravessamentos politemporais faz com que sua poética seja permanentemente ativada e reativada por meio da alteridade. Cada dobra parece tensionar uma volta a mais em sua espiral poética que, como vimos, diz respeito, ao mesmo tempo, aos seus percursos artísticos e percursos de vida - uma vez que é por meio dela que o tempo da criação de si e do saberfazer artístico de Rubiane Maia voluem simultaneamente, tornando-se indiscerníveis. Nessa espiral poética,

\footnotetext{
${ }^{89}$ SILVA, R.V. M. Op. cit., 2011, p. 68.

${ }^{90}$ SILVA, R.V. M. Op. cit., 2011, p. 69.

${ }^{91}$ Ibidem.

92 Expressão ligada ao debate político que perpassam as noções de biopolítica, proposta por Michel Foucault (2008), e de necropolítica, desenvolvida por Achille Mbembe (2018).

${ }^{93}$ Domingues, L. Op. cit., 2010, p. 19.

${ }^{94}$ Ibidem.
} 
cotidiano, corpo e processos de subjetivação demarcam presença. Além de comparecerem em articulações, composições e intensidades distintas - nas quais é a vazão do desejo de outrar-se, de Maia, que está em questão essas presenças tornam-se peças e engrenagens umas das outras, nutrindo, inclusive, o modo singular como Rubiane Maia toca e agencia, em seu saber-fazer artístico, a atualidade e a pertinência da proposta de aproximação entre arte, vida e obra na contemporaneidade. A esse respeito, ela mesma nos diz: "Mais do que misturar arte e vida, o que queremos é apresentar uma perspectiva mais expansiva de relações entre a arte e a vida." ${ }^{95}$

Como a artista apresenta esta perspectiva? Aos nossos olhos, via o acionamento da experiência estética como âmbito no qual se agencia um trabalho ético sobre si, e que ao fazer dos processos de arte sensações de vida - e vice-versa - convergiria para o exercício permanente de um ethos. Processo que assume a dimensão da relação arte e vida como "vivência partilhada, em um apelo estético que convida à diluição dos contornos juntos à potência de criação." ${ }^{\prime 96}$ Atravessa-nos a tendência dos seus trabalhos em estabelecerem um "contato singular e inesgotável com o gesto na experiência estética" ${ }^{97}$, conduzindo-nos, portanto, à reflexão sobre as possibilidades e as potencialidades que envolvem a formalização da dimensão estética da própria existência como obra de arte tal qual evocaram Friedrich Nietzsche (1992; 2001) e Michel Foucault (1984; 1985). Tendência na qual a arte desvia de suas leis internas e a atenção estética se volta à perscrutação e à extração do poético da vida. Ações que, ao definir e redefinir constantemente o foco de atenção para formas de criação de si, e em processo - tensionadas via os agenciamentos dos universos espaciotemporais com as repercussões afetivas de Rubiane Maia - produzem determinados registros e resíduos, presentes nos interstícios de suas voluções poéticas e que permitem colocar, em destaque, uma das linhas de força que tendem à constituição de sua singularidade poética: o diferir como “experimentação da potência estética de um exercício ético" ${ }^{98}$ - conduzindo a artista, através de seu tempo da criação, à maquinação de perspectivas mais expansivas de relações entre a arte e a vida - tal qual vimos junto a performance "O Jardim" (2015), por exemplo.

Ao escapar à lógica do encadeamento cronológico, a fim de afirmar a invenção de si via engendramentos criativos politemporais, o que estaria em jogo - não só no âmbito do tempo da criação de Rubiane Maia, mas, também nos de inúmeros outros artistas de diferentes contextos nacionais - seria a produção de outros equivalentes sensíveis da realidade, distintos daqueles escamoteados pelo imaginário de poder hegemônico da arte. Vetor que convida à reflexão da instauração da práxis vital como nascedouro de novas e potentes dimensões da criação, distintas das exortadas pelos sistemas de valores essencialmente artísticos. Vetor cuja complexidade, que evoca, impõe a necessidade em termos de lidar permanentemente com os desafios teórico-crítico colocados pelo caráter processual, dinâmico e politemporal da criação, que transborda o ato criador e a obra em direção à indiscernibilidade entre arte, vida e obra -desestabilizando e atualizando o campo de estudos dos processos de criação da/na arte contemporânea.

\footnotetext{
${ }^{95}$ SILVA, R.V. M. Op. cit., 2011, p. 113.

${ }^{96}$ Ibidem, p. 76.

${ }^{97}$ Ibidem, p. 98.

${ }^{98}$ Domingues, L. Op. cit., 2010, p. 135.
} 


\section{Referências bibliográficas}

Agamben, G. O que é o contemporâneo? e outros ensaios. Tradução Vinícius NicastroHonesko. Chapecó: Argos, 2009.

AlVES, L. F. Arte e vida em obra: a poética biografemática de Rubiane Maia. 2020. 300 f. Dissertação (Mestrado em Artes) - Programa de Pós-Graduação em Artes, Centro de Artes, Universidade Federal do Espirito Santo, Vitória, 2020.2 Disponível em: $<$ http://portais4.ufes.br/posgrad/teses/tese_14710_DISSERTA\%C7\%C3O\%20FINAL\%20LINDOMBERTO\%20 FERREIRA\%20ALVES.pdf>. Acesso em: 25 de set. de 2020.

BARTHES, R. Escritores e escreventes. In: BARTHES, R. Crítica e verdade. Tradução Leyla Perrone-Moisés. São Paulo: Perspectiva, 2013. p. 31-39.

BENJAMIN, W. Obras escolhidas: magia e técnica, arte e politica: ensaios sobre literatura e história da cultura - v. 1 . Tradução Sergio Paulo Rouanet. São Paulo: Brasiliense, 1985. Passagens. Tradução Irene Aron. Belo Horizonte: Editora UFMG, 2009.

Blanchot, M. O espaço literário. Tradução Álvaro Cabral. Rio de Janeiro: Rocco, 2011. BOURRIAUD, N. Formas de vida: a arte moderna e a invenção de si. São Paulo: Martins Fontes, 2011.

CARdoso, T. S. A epistemologia da mediação em Bruno Latour. 2015. 284 f. Tese (Doutorado em Tecnologias da Inteligência e Design Digital) - Programa de Pós-Graduação em Tecnologias da Inteligência e Design Digital, Faculdade de Ciências Exatas e Tecnologia, Pontifícia Universidade Católica de São Paulo, São Paulo, 2015. Disponível em: <https://tede2.pucsp.br/bitstream/handle/18191/1/Tarcisio\%20de\%20Sa\%20Cardoso.pdf>. Acesso em: 10 de mar. de 2020.

Castro, Eduardo Viveiros de. O recado da mata. In: Kopenawa, Davi \& Albert, Bruce. A queda do céu: palavras de um xamã yanomami. Tradução Beatriz Perrone-Moisés. São Paulo: Companhia das Letras, 2015. p. $11-41$.

DeleuZE, G. A dobra: Leibiniz e o barroco. Tradução Luiz Orlandi. Campinas: Papirus, 1991. Bergsonismo. Tradução Luiz Orlandi. São Paulo: Editora 34, 1999.

Diferença e repetição. Tradução Luiz Orlandi e Roberto Machado. São Paulo: Graal, 2006.

Didi-Huberman, G. Atlas ou le gais avoir inquiet: L'œil de l'histoire 3. Paris: Les éditions de Minuit, 2011. Diante do tempo: história da arte e anacronismo das imagens. Tradução Vera Casa Nova \& Márcia Arbex. Belo Horizonte: Editora UFMG, 2015.

DOMINGUES, L. À flor da pele: subjetividade, clinica e cinema no contemporâneo. Porto Alegre: Sulina, 2010. Ensaios de subjetivação: ethopoética, cartografemas e ethografias. In: LEÃO, A. et al (org.). Produção de subjetividade e institucionalismo: experimentaçõespoliticas e estéticas. Curitiba: Appris, 2017. p. 181-197. Foucault, M. O Nascimento da clínica. Tradução Roberto Machado. Rio de Janeiro: Forense Universitária, 1977. História da sexualidade, vol. II: O uso dos prazeres. Tradução Maria Thereza da Costa Albuquerque.

Rio de Janeiro: Graal, 1984.

História da sexualidade, vol. III: O cuidado de si. Tradução Maria Thereza da Costa Albuquerque Rio de Janeiro: Graal, 1985. 
A ética do cuidado de si como prática da liberdade. In: FoUCAULT, M. Ética, sexualidade, política. Coleção Ditos \& Escritos, vol. V. Tradução Elisa Monteiro e Inês Autran Dourado Barbosa. Rio de Janeiro: Forense Universitária, 2004, p. 264-287.

Arqueologia das ciências e história dos sistemas de pensamento. Coleção Ditos \& Escritos, vol. II.

Tradução Elisa Monteiro. Rio de Janeiro: Forense Universitária, 2005.

O nascimento da biopolítica. Tradução Eduardo Brandão. São Paulo: Martins Fontes, 2008.

A ordem do discurso: aula inaugural no Collège de France, pronunciada em 2 de dezembro de 1970.

Tradução Laura Fraga de Almeida Sampaio. São Paulo: Edições Loyola, 2012.

Frémont, C. Philosophie pour le temps présent. In: L'Yvonnet, F.; FrÉMONT, C. (org.). Cahier de l'Herne No 94:Michel Serres. Paris: Éditions de l'Herne, 2010. p. 17-26.

GUATTARI. F. Caosmose: um novo paradigma estético. Tradução Ana Lúcia de Oliveira \& Lúcia Cláudia Leão. Rio de Janeiro: Editora 34, 1992.

JACQUES, P. B. Montagem urbana: uma forma de conhecimento das cidades e do urbanismo. In: JACQUES, P. B.; BRITTO, F. D.; DRUMMOND, W. (orgs.). Experiências metodológicas para compreensão da complexidade da cidade contemporânea - Tomo IV. Salvador: EDUFBA, 2015. p. 47-94.

Kopenawa, Davi \& Albert, Bruce. A queda do céu: palavras de um xamã yanomami. Tradução Beatriz PerroneMoisés. São Paulo: Companhia das Letras, 2015.

KRENAK, Ailton. Ideias para adiar o fim do mundo. São Paulo: Companhia das Letras, 2020.

LATOUR, B. Jamais fomos modernos: ensaio de antropologia simétrica. Tradução Carlos Irineu da Costa. Rio de janeiro: Editora 34, 1994.

Não é a questão. Tradução Gabriel Banaggia. Revista de Antropologia da UFSCAR, Florianópolis, v. 7, n. 2, p. 73-77, jul.-dez. 2015. Disponível em: <http://www.rau.ufscar.br/wpcontent/uploads/2016/10/Serto\%CC\%83es_7-2_05-Na\%CC\%83o-e\%CC\%81-a-

questa\%CC\%83o_BrunoLatour.pdf $>$. Acesso em: 10 de mar. de 2020.

MBEMBE, A. Necropolitica: biopoder, soberania, estado de exceção, política da morte. Tradução Renata Santini. São Paulo: N-1 edições, 2018.

Medeiros, M. B. Sugestões de conceitos para reflexão sobre a arte contemporânea a partir da teoria e prática do grupo de pesquisa corpos informáticos. In: ARJ, Natal/Porto Alegre, v. 4, n. 1, p. 33-47, jan.-jun. 2017. Disponível em: <https://periodicos.ufrn.br/artresearchjournal/article/view/11808/8698>. Acesso em: 10 de mar. de 2020.

NieTZSCHE, F. O nascimento da tragédia, ou Helenismo e pessimismo. Tradução J. Guinsburg. São Paulo: Companhia das Letras, 1992.

A gaia ciência. Tradução Paulo César de Souza. São Paulo: Companhia das Letras, 2001.

PELBART, P. P. A vertigem por um fio: políticas da subjetividade contemporânea. São Paulo: Editora Iluminuras, 2000. O tempo não reconciliado: Imagens de tempo em Deleuze. São Paulo: Perspectiva, 2004.

Tempos agonísticos. In: PESSOA, F.; CANTON, K. (orgs.). Sentidos e arte contemporânea Seminários Internacionais Museu Vale do Rio Doce. Vila Velha: Museu Vale do Rio Doce, 2007. p. 68-79.

RANCIÈRE, J. A partilha do sensivel. Tradução Mônica Costa Netto. São Paulo: Editora 34, 2005. 
Em que tempo vivemos? Tradução Donaldson M. Garschagen. In: Revista Serrote, n. 16, p. 203222, mar. 2014.

RIBEIRO, A. C. T. Sociabilidade, hoje: leitura da experiência urbana. In: Caderno CRH, Salvador, v. 18, n. 45, p. 411-422, set./dez. 2005. Disponível em: <https://portalseer.ufba.br/index.php/crh/article/view/18535/11911>. Acesso em: 29 de jan. de 2019.

SALLES, C. A. Gesto Inacabado: processo de criação artístico. São Paulo: FAPESP, 1998. Redes da criação: construção da obra de arte. Vinhedo: Horizonte, 2006.

SANTOS, M. E. E. A multiplicidade como teoria da comunicação na filosofia de Michel Serres e suas contribuições para o pensamento em educação. 2016. 248 f. Tese (Doutorado em Educação) - Programa de Pós-Graduação em Educação, Faculdade de Educação, Universidade Estadual de Campinas, Campinas, 2016. Disponível em: <http://repositorio.unicamp.br/jspui/bitstream/REPOSIP/319153/1/Santos_MariaEmanuelaEstevesdos_D.pdf >. Acesso em: 10 de mar. de 2020.

SANTOS, M. Por uma Geografia cidadã: por uma epistemologia da existência. In: Boletim Gaúcho de Geografia, Porto Alegre, v. 21, n. 1, p. 7-14, ago. 1996. Disponível em: <https://seer.ufrgs.br/bgg/article/view/38613>. Acesso em: 10 de mar. de 2020.

SERRES, M. Le système de Leibniz et sés modèles mathématiques. Paris: P.U.F., 1968. . Genèse. Paris: Grassei, 1982.

Diálogo sobre a ciência, a cultura e o tempo: conversas com Bruno Latour. Tradução Serafim Ferreira e João Paz. Lisboa: Instituto Piaget, 1996.

SILVA, R. V. M. Desvios, sobre arte e vida na contemporaneidade. 2011. 142 f. Dissertação (Mestrado em Psicologia Institucional) - Programa de Pós-Graduação em Psicologia Institucional, Departamento de Psicologia, Universidade Federal do Espírito Santo, Vitória, 2011. Disponível em: <http://repositorio.ufes.br/bitstream/10/6730/1/Rubiane\%20Vanessa\%20Maia\%20da\%20Silva.pdf>. Acesso em: 29 de jan. de 2019 .

O JARDIM | Rubiane Maia | 8 performances | Terra Comunal - Marina Abramović + MAI. Direção: Felipe Lima. São Paulo: Mão Direita, 2015. 1 video (3 min 31 s). Casa Redonda. Disponível em: <https://www.youtube.com/watch?v=pj7iPi05nag\&t=16s >. Acesso em: 27 dez. 2017.

"Statement": carta de intenções artísticas. In: SILVA, R. V. M. Homepage Rubiane Maia, [S.I., s.d.]. Disponível em: <https://www.rubianemaia.com/>. Acesso em: 15 de mar. de 2018.

Sodré, M. Exu inventa o seu tempo. In: SodrÉ, M. Pensar nagô. Petrópolis: Vozes, 2020. p. 181-192. 